\title{
Analysis of the Influence of Brand Consciousness, Materialism, Social Comparison, Fashion Innovativeness, and Fashion Involvement on Attitude Towards Purchasing Luxury Fashion Goods and Repurchase Intention of Luxury Fashion Goods Furla Customers in Surabaya
}

\author{
Sevira Chandra ${ }^{\mathrm{a} *}$, Amelia $^{\mathrm{b}}$, Ronald ${ }^{\mathrm{c}}$ \\ ${ }^{a}$ Vira.salsa12@gmail.com \\ ${ }^{a}$ Barchelor of Management Student at Pelita Harapan University, Surabaya 60234, Indonesia \\ ${ }^{b, c}$ The Lecturer of Barchelor of Management at Pelita Harapan University, Surabaya 60234, Indonesia
}

\begin{abstract}
Luxury fashion goods is a dynamic and competitive industry. Nowadays, customers are not only buying luxury goods, but also looking for added value that can only be obtained from these luxury goods, in determining them to be loyal customers. As a well-known brand with a rich Italian culture, Furla needs to always strive on how to continuously improve product quality, product innovation and other factors, by working to increase sales and build customer loyalty to Furla products. The purpose of this study was to evaluate and analyze the effect of brand consciousness, fashion innovativeness, fashion involvement, materialism and social comparison on Repurchase Intention through Attitude Towards Purchasing Luxury Fashion Goods at Furla in Surabaya. This research is a causal research, which uses a quantitative approach with analysis techniques using SPSS version 22.0 software. Data collection in this study was carried out by distributing questionnaires to 135 respondents, with the characteristics that respondents are customers of the Furla Store in Surabaya, women, aged 18-60 years, residing in Surabaya, have bought and used Furla products at least 2 times in The last 1 year, and still using Furla products until the time this research was conducted. Based on the research that has been done, the results show that there are two variables that most influence attitude towards purchasing luxury fashion goods are fashion innovativeness with a regression coefficient of 0.266 and brand consciousness with a regression coefficient of 0.212. So that Furla in Surabaya needs to increase the influence of these variables, to increase his attitude towards purchasing luxury fashion goods which will affect repurchase intention.
\end{abstract}

Keywords: fashion innovativeness, brand consciousness, fashion involvement, social comparison, materialism, attitude towards purchasing luxury fashion goods, repurchase intention

\section{Introduction}

In this era of globalization, people are increasingly interested in fashion, especially in branded luxury goods. The concept of luxury itself has been used to prove the social status of the wearer as well as his strength. The definition of luxury is not only limited, but also a manifestation of identity, philosophy and culture. Therefore, consumers of luxury goods today, usually tend to seek special experiences that are more personal from a brand, not just buying a product (www.ducttapemarketing.com, downloaded on February 20, 2020).

Currently, producers also compete in implementing various marketing strategies and create their own attractiveness in order to satisfy consumer desires. Marketing strategy is a fundamental tool designed or planned to achieve the goals of a company by developing a sustainable competitive advantage through the entered market and the programs used to serve its target market (www.jurnal.id, downloaded on March 9, 2020).

From a historical perspective, the luxury goods industry has long been seen as a concept of consumerism that seems exaggerated. This is reflected in the product prices that are too high, the impression of being elite for the wearer, and so on. However, when the younger generation began to emerge and became one of the main consumers, consumer expectations for branded luxury goods began to change. Moral and 
ethical values are important for consumers. This new generation of luxury consumers has a higher social and environmental awareness than the previous generation and that's why they have high expectations for a fashion brand (www2.deloitte.com, downloaded February 12, 2020).

Manufacturers of branded goods have also adjusted their perspective on fashion. Manufacturers of branded goods are no longer based on the mindset that branded goods must be expensive and exclusive. Manufacturers of branded goods have realized that today's consumers are more likely to be attracted to products that have new ideas (www.tirto.id, downloaded January 29, 2020).

Furla is one of the brands favored by the Indonesian people, especially the millennial generation. Furla is one of the world's famous bag brands, which is in great demand by women ranging from artists, entrepreneurs, and career women. This brand was founded in 1927 in Bologna by Aldo and Margherita Furlanetto. Furla products which are made from leather and intended for women have finally grown into a giant company and are known to the world community. In 1955, Aldo opened the first Furla store on Via Ugo Bassi, Bologna (www.pierotucci.com, downloaded on March 1, 2020).

In 2012, Furla shifted elite brands such as Hermes and Louis Vuitton as the most popular bags that year with their candy bag line of products. Furla products that are not monotonous with their colorful characteristics are an added value for the brand, especially its unique candy bag design. This is also supported by good quality, strategic store locations, and the existence of the Furla online shop so that it is easily accessible to consumers. These factors encourage consumers to repurchase Furla products (www.fimela.com, downloaded on February 26, 2020).

Luxury consumers have their own reasons for buying back Furla products. Therefore, it is important for Furla products to always increase Repurchase Intention. The reasons for the importance of increasing Repurchase Intention as stated by Graciola et al. (2018) because Repurchase Intention shows a person's plan to frequently do shopping in a store. Researchers say that there is a relationship between attitude towards purchasing luxury fashion goods and purchase intention (Zhang \& Kim., 2013). In addition, research on the effect of attitude towards purchasing luxury fashion goods on purchase intention was also conducted in India. In this study, it was concluded that brand consciousness and materialism have an effect on attitude (Bhatia., 2018).

In this study, we will include variations of brand consciousness, materialism, social comparison, fashion innovativeness, and fashion involvement as factors that influence attitude towards purchasing luxury fashion goods on repurchase intention. The formation of Repurchase Intention can be seen by the tendency of customers to be loyal to Furla products, which is shown by the intention of customer repurchase to buy from the Furla store in Surabaya as the first choice.

\section{Litterature Review}

\subsection{Theories and Hypotheses}

\subsubsection{Brand Consciousness}

According to Jiang and Shan (2016), brand consciousness or brand awareness refers to the psychological orientation of brand names experienced by consumers when they are in a process before making a purchase. According to Siddique and Rashidi (2015), brand consciousness does not only include knowledge about a brand or choosing a brand among other brands, but also about the value of the brand itself, where the brand has an image, quality, and attributes that can distinguished from other brands. According to Liao and Wang in Giovanni et al. (2015), well-known brands offer consumers a sense of familiarity so that this creates an attachment between consumers and brands, where in the end consumers feel risk-free when buying the brand. 
H1: Brand Consciousness has a significant effect on Attitude Towards Purchasing Luxury Fashion Goods

\subsubsection{Materialism}

According to Bhatia (2017), materialism refers to the ownership of material objects that aim to realize life goals and ideal social status in society. According to Kilbourne and Pickett (in Alzubaidi et al.: 2017), materialistic values grow rapidly in developing countries where this can be seen from consumer behavior that mimics the consumption of western-style objects and lifestyles. According to Brown et al. (2015) consumers with high materialism want more income and also want to be able to spend more money, than consumers with low materialism. Sirgy in Lipovcan et al. (2015) also stated that individuals with high materialism are accustomed to setting high targets that tend to be impossible to achieve, which causes dissatisfaction and sadness for them.

H2: Materialism has a significant effect on Attitude Towards Purchasing Luxury Fashion Goods.

\subsubsection{Social Comparison}

According to Sun et al. (2016), social comparison is a means used by individuals to measure whether their behavior can be categorized as true or correct. What these individuals compare are their abilities and conditions with the social community. According to Zheng et al. (2018), consumers conduct social comparisons by comparing their feelings, thoughts, and appearances with others to gain knowledge about themselves. Festinger (in Zheng et al.: 2018) suggests that there are two ways individuals use social comparisons, namely downward comparisons and upward comparisons. In an upward comparison, the individual compares himself to the comparative target that is more superior while in the downward comparison, the individual compares himself with the lower comparison target.

H3: Social Comparison has a significant effect on Attitude Towards Purchasing Luxury Fashion Goods.

\subsubsection{Fashion Innovativeness}

According to Rogers (1995) in Kim and Zhang (2013), innovativeness is a person's desire to explore new ideas, new products, and new services first compared to other people in their social environment. Therefore, someone with a high level of fashion innovativeness always tries to look different by exploring new and unique styles to maintain their status as an innovator, which will be followed by those around them. According to Muzinich (2003) in Kim and Zhang (2013), fashion innovativeness is identical to individuals who have high incomes, tend to be younger, prefer to socialize, are resilient in facing risks, have a high level of social participation, and have opinions that are trusted by others. According to Jai and Tung (2015), individuals who have high fashion innovativeness or fashion innovators are a very vital consumer segment.

H4: Fashion Innovativeness has a significant effect on Attitude Towards Purchasing Luxury Fashion Goods.

\subsubsection{Fashion Involvement}

According to Kim and Zhang (2013), involvement is the level where consumers feel that a purchase decision is very important to him. Fashion involvement is an individual's perception of the relevance of a fashion trend to its needs, values and interests. According to Szczepaniak (2015), Involvement is a condition where consumers decide that a product or service is very important and interesting. In terms of fashion, involvement in dressing is defined as the awareness of the individual in the clothes he wears in various situations. There 
are four dimensions to Fashion involvement, namely product involvement, purchase decision involvement, consumption involvement, and advertising involvement.

\section{H5: Fashion Involvement has a significant effect on Attitude Towards Purchasing Luxury Fashion} Goods.

\subsubsection{Attitude Towards Purchasing Luxury Fashion Goods}

According to Zhang and Kim (2013), attitude towards behavior is a process of assessing the extent to which a person likes or supports the behavior. Attitude or attitude is an evaluative effect of positive or negative feelings of an individual in carrying out certain behaviors. Ladero et. al. (2015) defines consumer attitudes as very important in social psychology, which is the key to explaining consumer behavior in general that can be socially responsible. Individual attitude is a concept that has three main components, namely cognitive elements (trust), affective elements (social and feeling), and active or deliberate elements (elements relating to behavior, actions, tendencies in acting and responding to things).

H6: Attitude Towards Purchasing Luxury Fashion Goods has a significant effect on Repurchase Intention.

\subsection{Research Model}

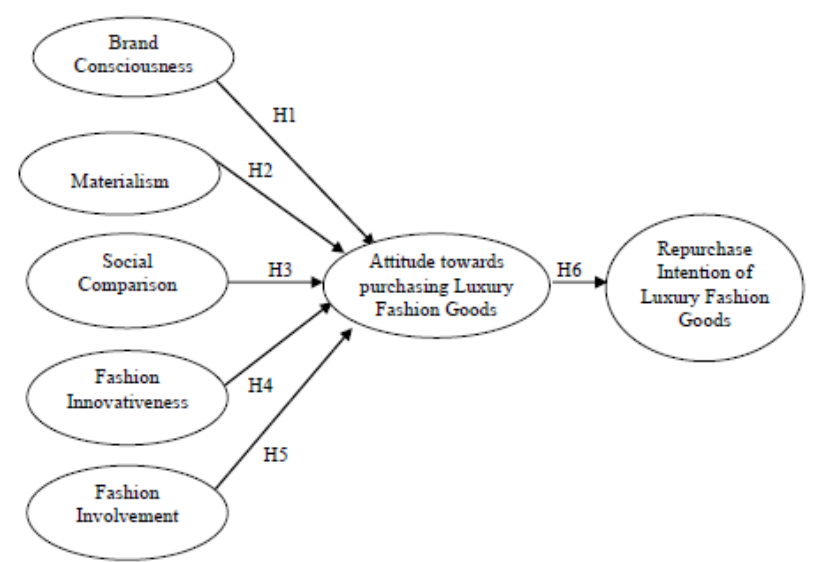

Figure 2.1: The Framework of Kesearch Model

\section{Research Methods}

Population is a generalization area consisting of certain qualities and characteristics that the researcher determines to study and draw conclusions (Sugiyono in Sarwono, 2010). From this understanding, it can be understood that the population is an area that is determined to be researched by studying and drawing conclusions from the research results. In this case, the population used is consumers who purchase Furla products at Ciputra World, and Tunjungan Plaza in Surabaya. Judging from the number, the population to be used in this study is included in the population category with an unknown number, namely the population consisting of elements. which is difficult to find the limit. The population used is male and female consumers who make purchases of Furla products in Surabaya. Guided by the sample size set by Ferdinand (2002), it was determined that the number of indicators used in this study was 27 indicators. Thus, the minimum sample size 
is 135-270 respondents. For this study, the number of respondents targeted was 135 people, where respondents were drawn according to the characteristics of the sample previously described. Data collection will be done by distributing questionnaires to respondents in accordance with the characteristics of the sample that this study has. The questionnaire was filled in at the place where the respondent was when the questionnaire was given. After filling in the questionnaire, the respondent can return the questionnaire that has been filled in to the researcher and then the researcher will select the results of the questionnaire. The selected questionnaire is a questionnaire that is completely filled in and in accordance with the filling instructions. After the selection, the selected questionnaires will be tabulated and processed further. The tabulated data was then tested on the research model using SPSS 22.0 software. The questionnaire in this study will be divided into two parts, namely the first part contains questions to obtain general information about the respondent's profile; and the second part contains several statements to obtain research data and analyze the influence of brand consciousness, materialism, social comparion, fashion innovativeness, and fashion involvement, as factors that have a significant effect on attitutde towards purchasing luxury fashion goods on repurchase intention. The questions on the questionnaire were made using a numeric scale (Likert scale) 1-5 to get interval data.

\section{Result and Discussion}

\subsection{Assessment of Measurement Model}

Tabel 4.3. Descriptive Statistics

\begin{tabular}{|c|c|c|c|c|c|}
\hline & $\mathrm{N}$ & Min & $\operatorname{Max}$ & Mean & Std. Deviation \\
\hline $\mathrm{BC} 1$ & 135 & 2 & 5 & 3.69 & .824 \\
\hline BC 2 & 135 & 2 & 5 & 3.82 & .880 \\
\hline BC 3 & 135 & 2 & 5 & 3.89 & .843 \\
\hline BC 4 & 135 & 2 & 5 & 3.84 & .732 \\
\hline BC 5 & 135 & 2 & 5 & 3.85 & .718 \\
\hline BC & 135 & 2.0 & 5.0 & 3.819 & .6744 \\
\hline M 1 & 135 & 2 & 5 & 3.68 & .779 \\
\hline M 2 & 135 & 2 & 5 & 3.76 & .859 \\
\hline M 3 & 135 & 2 & 5 & 3.74 & .855 \\
\hline M 4 & 135 & 2 & 5 & 3.79 & .859 \\
\hline M 5 & 135 & 2 & 5 & 3.76 & .868 \\
\hline M & 135 & 2 & 5 & 3.74 & .732 \\
\hline SC 1 & 135 & 2 & 5 & 3.62 & .800 \\
\hline SC 2 & 135 & 2 & 5 & 3.86 & .865 \\
\hline SC 3 & 135 & 2 & 5 & 3.77 & .801 \\
\hline
\end{tabular}




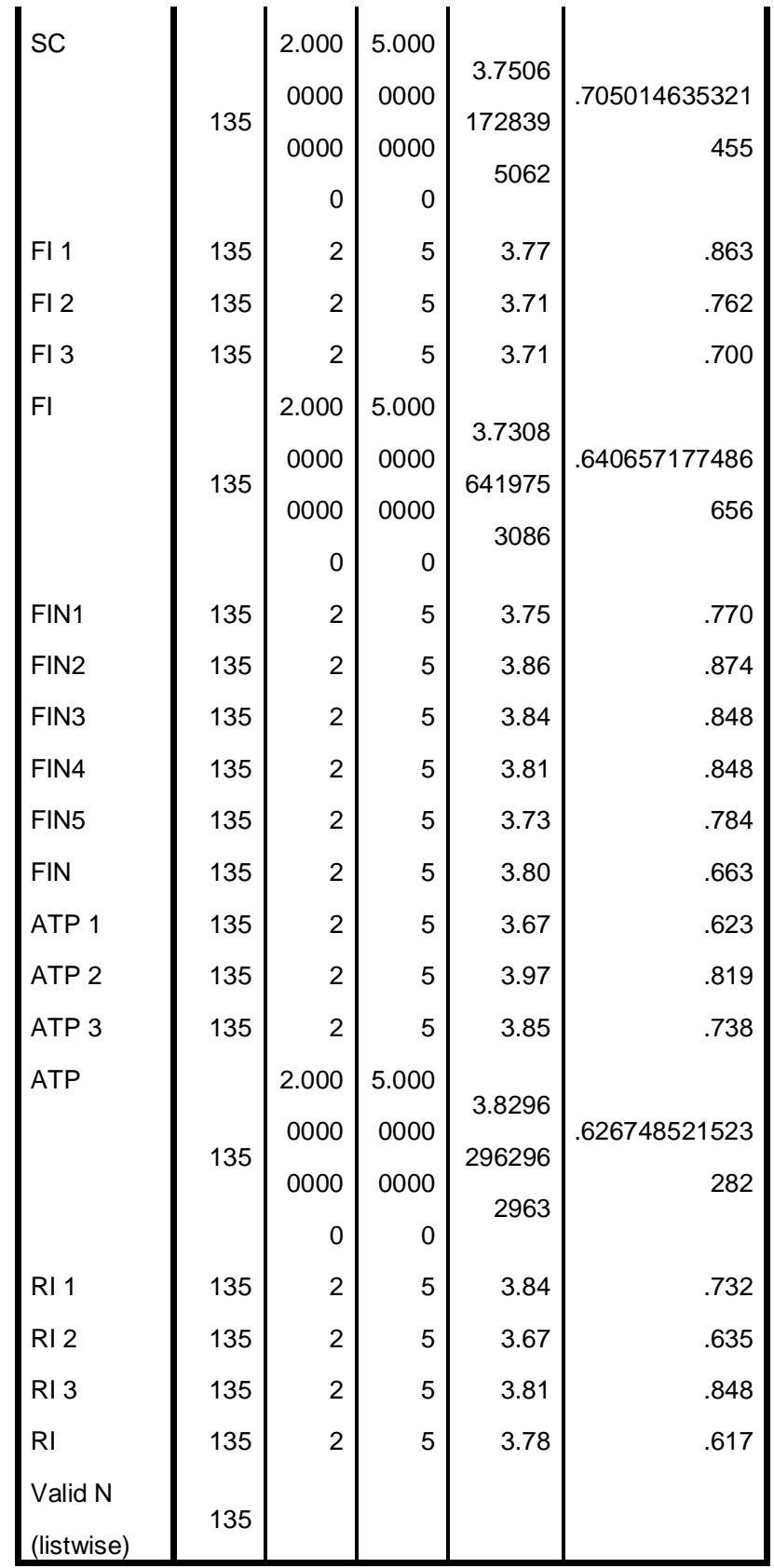

Table 4.4 Results of the Coefficient of Determination $1\left(\mathrm{R}^{2}\right)$

\begin{tabular}{|c|c|}
\hline Variabel & Adjusted R $^{2}$ \\
\hline BC,SC,M,FI,FIN*ATP & 0.825 \\
\hline
\end{tabular}

Source: Data processed, 2020 
Table 4.5 Results of the Coefficient of Determination $1\left(\mathrm{R}^{2}\right)$

\begin{tabular}{|c|c|}
\hline Variabel & $\mathrm{R}^{2}$ \\
\hline ATP*RI & 0.655 \\
\hline
\end{tabular}

Tabel 4.6 F Test Results

\begin{tabular}{|l|l|l|l|}
\hline Variabel & Sig. & Standar & Keterangan \\
\hline $\begin{array}{l}\text { BC, M, SC, FI, } \\
\text { FIN*ATP }\end{array}$ & 0.00 & 0.05 & Hypothesis accepted \\
\hline ATP*RI & 0.00 & 0.05 & Hypothesis accepted \\
\hline
\end{tabular}

Source: From data processing using SPSS 22.0 (2020)

Tabel 4.7 T Test Results

\begin{tabular}{|c|c|c|l|}
\hline Variabel & Sig. & Standar & Keterangan \\
\hline BC*ATP & 0.002 & 0.05 & Hypothesis accepted \\
\hline M*ATP & 0.020 & 0.05 & Hypothesis accepted \\
\hline SC*ATP & 0.024 & 0.05 & Hypothesis accepted \\
\hline FI*ATP & 0.001 & 0.05 & Hypothesis accepted \\
\hline FIN*ATP & 0.007 & 0.05 & Hypothesis accepted \\
\hline ATP*RI & 0.000 & 0.05 & Hypothesis accepted \\
\hline
\end{tabular}

Based on the data processing carried out, the final result is that of the 7 proposed hypotheses, all hypotheses can be accepted. From the literature review, it is found that the brand consciousness variable has a significant positive effect on attitude towards purchasing luxury fashion goods, the materialism variable has a significant positive effect on attitude towards purchasing luxury fashion goods, social comparison variables have a significant positive effect on attitude towards purchasing luxury fashion goods, fashion involvement has a significant positive effect on attitude towards purchasing luxury fashion goods, fashion innovativeness has a significant positive effect on attitude towards purchasing luxury fashion goods, and In the end, the variable attitude towards purchasing luxury fashion goods has a significant positive effect on repurchase intention. Overall, the results of this study indicate that the variables brand consciousness, materialism, social comparison, fashion involvement, and fashion innovativeness have a significant effect on attitude towards purchasing luxury fashion goods. Where the biggest influence on attitude towards purchasing luxury fashion goods is fashion innovativeness which is 0.266 . This is because Furla is one of the luxury goods brands that has its own uniqueness, especially in the design of its products, so that every season, Furla products always seem fresh and attractive. According to the research results, with the formation of fashion innovativeness, it will have a big influence on the formation of attitude towards purchasing luxury fashion goods at Furla in Surabaya. Where to build an attitude towards purchasing luxury fashion goods Furla in Surabaya, customers are also significantly influenced by other variables, namely brand consciousness, fashion involvement, materialism and social comparison owned by Furla in Surabaya. In addition to these variables, data from the research results show that Furla customers in Surabaya also emphasize brand consciousness. The Furla brand has been accepted by the luxury goods enthusiast community in Surabaya so there is a high brand awareness. The Furla brand has been associated with relatively high prices but still affordable and good production quality. 


\subsection{Hypotheses Testing}

Table 4.2: Summary of Testing Results.

\begin{tabular}{|l|c|}
\hline Hypotheses & Analysis \\
\hline H1: Brand Consciousness has a significant effect on Attitude Towards Purchasing Luxury & Accepted \\
Fashion Goods & Accepted \\
Hoods. & \\
\hline H3: Social Comparison has a significant effect on Attitude Towards Purchasing Luxury & Accepted \\
Fashion Goods. & \\
\hline $\begin{array}{l}\text { H4 : Fashion Innovativeness has a significant effect on Attitude Towards Purchasing } \\
\text { Luxury Fashion Goods }\end{array}$ & \\
\hline $\begin{array}{l}\text { H5 : Fashion Involvement has a significant effect on Attitude Towards Purchasing Luxury } \\
\text { Fashion Goods. }\end{array}$ & Accepted \\
\hline $\begin{array}{l}\text { H6 : Attitude Towards Purchasing Luxury Fashion Goods has a significant effect on } \\
\text { Repurchase Intention. }\end{array}$ & Accepted \\
\hline
\end{tabular}

\subsection{Discussion}

\subsubsection{The effect of Brand Consciousness toward Attitude Towards Purchasing Luxury Fashion Goods}

The fashion innovation variable is one of the important variables that affects the level of attitude towards purchasing luxury fashion goods. The way to improve these indicators is to make a bag design with a diagonal zipper that can add aesthetic value to the wearer. In addition, by issuing a candy bag design with 2 color combinations and color gradation designs such as tie dye; provides a variety of payment methods, such as credit cards, debit cards, electronic wallets, and others. In addition, it can be added by direct contact to the WA Furla salesperson as Furla's personal shopper and also inserting product advertisements into media such as billboards, magazines, and television advertisements. For Furla customers, an e-newspaper and e-catalog sent to the customer's email

\subsubsection{The effect of Materialism toward Attitude Towards Purchasing Luxury Fashion Goods.}

The Brand Consciousness variable is an important variable to increase attitude towards purchasing luxury fashion goods for Furla customers in Surabaya. The way to improve these indicators is by using Furla to issue a signature series such as using a pendulum of real gold at a higher price; add unique design features such as geometric patterned bag which gives an elegant and modern style; issued Furla croco mini bags with 25 items in each country; provide after-service by consulting directly to Furla outlets; and using premium quality materials such as cow, snake and crocodile leather.

\subsubsection{The effect of Social Comparison toward Attitude Towards Purchasing Luxury Fashion Goods.}

The fashion involvement variable is also an important variable in order to build an attitude towards purchasing luxury fashion goods. As for how to improve these indicators, Furla must issue special promos for members or customers; provide comfortable sofas, dishes such as soft drinks or light snacks so that consumers get the best service; ask consumers to leave a feedback card at the outlet after shopping; holding an Art Award competition that gathers artists to create; and finally collaborated with Blackpink and Selena Gomez. 


\subsubsection{The effect of Fashion Innovativeness toward Attitude Towards Purchasing Luxury Fashion Goods}

The materialism variable is important to build an attitude towards purchasing luxury fashion goods towards a product or company. As for how to improve these indicators is to make a mini questionnaire containing questions about popular fashion, popular trends and also public figures who enjoy doing; collaborating with online platforms such as Lazada, Shopee, and so on and creating a Furla official store so that consumers can more easily buy Furla products without having to come to outlets; Furla chose Kendall Jenner and Kylie Jenner as one of the models for the Furla brand; Furla must maintain both offline services at outlets and official stores in Indonesian e-commerce such as Shopee or Tokopedia.

\subsubsection{The effect of Fashion Involvement toward Attitude Towards Purchasing Luxury Fashion Goods.}

The social comparison variable is also a very important variable in determining attitude towards purchasing luxury fashion goods towards a product. The way to improve these indicators is to work in Indonesia with Syahrini and Nagita Slavina as public figures, collaborating with Charlene Choi, a CanadianHong Kong singer and actress. With Choi as endorser; Furla can challenge by using hashtags that invite their followers to take selfies using Furla products.

\subsubsection{The effect of Attitude Towards Purchasing Luxury Fashion Goods toward Repurchase Intention}

The variable attitude towards purchasing luxury fashion goods is a very important variable in determining repurchase intention. The way to improve these indicators is to provide weekly information by providing messages via e-mail and Instagram features related to fake products in circulation; Furla must collaborate with the authorities and also the Director General of Intellectual Property Rights to eradicate pirated products on the market and also hold events on Instagram and invite consumers to come together to use the hashtag \#NoFakeFurla so as not to support using fake Furla products.

\section{Conclusion}

\subsection{Managerial Implications}

Table 5.1: Managerial Implications

\begin{tabular}{|c|c|}
\hline Current Research & Managerial Implications \\
\hline $\begin{array}{lll}\text { Senses } & \text { significantly } & \text { affected } \\
\text { Emotions. } & & \end{array}$ & $\begin{array}{l}\text { The way to improve these indicators is to make a bag design with a } \\
\text { diagonal zipper that can add aesthetic value to the wearer. In addition, } \\
\text { by issuing a candy bag design with } 2 \text { color combinations and color } \\
\text { gradation designs such as tie dye; provides a variety of payment } \\
\text { methods, such as credit cards, debit cards, electronic wallets, and } \\
\text { others. In addition, it can be added by direct contact to the WA Furla } \\
\text { salesperson as Furla's personal shopper and also inserting product } \\
\text { advertisements into media such as billboards, magazines, and } \\
\text { television advertisements. For Furla customers, an e-newspaper and e- } \\
\text { catalog sent to the customer's email }\end{array}$ \\
\hline
\end{tabular}




\begin{tabular}{|c|c|}
\hline $\begin{array}{l}\text { Interior Design significantly affected } \\
\text { Emotions. }\end{array}$ & $\begin{array}{l}\text { The way to improve these indicators is by using Furla to issue a } \\
\text { signature series such as using a pendulum of real gold at a higher } \\
\text { price; add unique design features such as geometric patterned bag } \\
\text { which gives an elegant and modern style; issued Furla croco mini } \\
\text { bags with } 25 \text { items in each country; provide after-service by } \\
\text { consulting directly to Furla outlets; and using premium quality } \\
\text { materials such as cow, snake and crocodile leather. }\end{array}$ \\
\hline $\begin{array}{l}\text { Signage significantly affected } \\
\text { Emotions. }\end{array}$ & $\begin{array}{l}\text { As for how to improve these indicators, Furla must issue special } \\
\text { promos for members or customers; provide comfortable sofas, dishes } \\
\text { such as soft drinks or light snacks so that consumers get the best } \\
\text { service; ask consumers to leave a feedback card at the outlet after } \\
\text { shopping; holding an Art Award competition that gathers artists to } \\
\text { create; and finally collaborated with Blackpink and Selena Gomez. }\end{array}$ \\
\hline $\begin{array}{l}\text { Facilities significantly affected } \\
\text { Emotions. }\end{array}$ & $\begin{array}{l}\text { As for how to improve these indicators is to make a mini } \\
\text { questionnaire containing questions about popular fashion, popular } \\
\text { trends and also public figures who enjoy doing; collaborating with } \\
\text { online platforms such as Lazada, Shopee, and so on and creating a } \\
\text { Furla official store so that consumers can more easily buy Furla } \\
\text { products without having to come to outlets; Furla chose Kendall } \\
\text { Jenner and Kylie Jenner as one of the models for the Furla brand; } \\
\text { Furla must maintain both offline services at outlets and official stores } \\
\text { in Indonesian e-commerce such as Shopee or Tokopedia. }\end{array}$ \\
\hline $\begin{array}{l}\text { Atmospherics significantly affected } \\
\text { Emotions. }\end{array}$ & $\begin{array}{l}\text { The way to improve these indicators is to work in Indonesia with } \\
\text { Syahrini and Nagita Slavina as public figures, collaborating with } \\
\text { Charlene Choi, a Canadian-Hong Kong singer and actress. With Choi } \\
\text { as endorser; Furla can challenge by using hashtags that invite their } \\
\text { followers to take selfies using Furla products. }\end{array}$ \\
\hline Staff significantly affected Emotions. & $\begin{array}{l}\text { The way to improve these indicators is to provide weekly information } \\
\text { by providing messages via e-mail and Instagram features related to } \\
\text { fake products in circulation; Furla must collaborate with the } \\
\text { authorities and also the Director General of Intellectual Property } \\
\text { Rights to eradicate pirated products on the market and also hold } \\
\text { events on Instagram and invite consumers to come together to use the } \\
\text { hashtag \#NoFakeFurla so as not to support using fake Furla products. }\end{array}$ \\
\hline
\end{tabular}

\section{References}

Ariyanto, Debby. (2018). Pengaruh Attitude, Subjective Norm, dan Perceived Behavioral Control terhadap Repurchase Intention E-Money. Jurnal Ilmu Manajemen Vol 6 No 4 - Jurusan Manajemen Fakultas Ekonomi Universitas Negeri Surabaya.

Balla, Badr Elgasim., Ibrahim, Dr. Siddig Balal., \& Ali, Dr. Abdel Hafiez. (2015). The Impact Of Relationship Quality On Repurchase Intention Towards The Customers Of Automotive Companies In Sudan. British Journal of Marketing Studies Vol.3, No.4, pp.1-15.

Brown, Kirk Warren., Kasser, Tim., Ryan, Richard M., \& Konow, James. (2015). Materialism, Spending, and Affect: An Event-Sampling Study of Marketplace Behavior and Its Affective Costs. Springer Science + Business Media Dordrecht. 
Chakraboty, Samit. (2016). An Explanatory study on Indian Young Consumers' Luxury Consumption : The Underlying Relationship of Interpersonal Influence, Brand Image, Brand Consciousness and Demographic Compone. International Journal of Current Engineering and Technology, E-ISSN 2277 4106, P-ISSN $2347-5161$.

Chen, Yan., Lu, Fangwen., \& Zhang, Jinan. (2017). Social comparisons, status and driving behavior. Journal of Public Economics.

Choi, Yung Kyun., Seo, Yuri., Wagner, Udo., \& Yoon, Sukki. (2018). Matching luxury brand appeals with attitude functions on social media across cultures. Journal of Business Research.

Chou, Shih-Wei \& Hsu, Chia-Shiang. (2015). Understanding online repurchase intention : social exchange theory and shopping habit. Springer-Verlag Berlin Heidelberg.

Civitcia, Nazmiye \& Civitcia, Asım., (2015). Social Comparison Orientation, Hardiness and Life Satisfaction in Undergraduate Students. Procedia - Social and Behavioral Sciences 205 ( 2015 ) 516 - 523.

Durmaz, Yakup., Demirag, Bulent., \& Cavusoglu, Sinan. (2020). Influence of Regret and Regret Reversing Effort on Dissatisfaction and Repurchase Intention after Purchasing Fashion Products. Preprints 2020, 2020030280.

Edward, S.-T., \& Wang, Jia-Rong Yu. (2016). Effect of product attribute beliefs of ready-to-drink coffee beverages on consumer-perceived value and repurchase intention. British Food Journal, Vol. 118 Iss 12 pp.

Giovannini, Sarah., Xu, Yingjiao., \& Thomas, Jane Boyd. (2015), Luxury fashion consumption and Generation Y consumers: self, brand consciousness, and consumption motivations., Journal of Fashion Marketing and Management: An International Journal, Vol. 19 Iss 1 pp.

Islam, Tahir., Sheikh, Zaryab., Hameed, Zahid., Khan, Ikram Ullah., \& Azam, Rauf I. (2018). Social comparison, materialism, and compulsive buying based on stimulus-response- model: a comparative study among adolescents and young adults. Young Consumers, Vol. 19 No. 1, pp. 19-37.

Isaid, Emad Naji \& Faisal, Mohd. Nishat. (2015). Consumers' Repurchase Intention Towards a Mobile Phone Brand in Qatar: An Exploratory Study Utilizing Theory of Reasoned Action Framework. Global Business Review 16(4) 594-608.

Jai, Tun-Min (Catherine) \& Tung, Tracie (Tsun-Yin). (2015). Fashion innovativeness, information technology innovativeness, and prior experience as factors influencing adoption of apparel mobile E-catalogs. Journal of Global Fashion Marketing: Bridging Fashion and Marketing, 6:3, 163-179.

Jiang, Ling. \& Shan, Juan. (2016). Counterfeits or Shanzhai? The Role of Face and Brand Consciousness in Luxury Copycat Consumption. Psychological Reports 2016, Vol. 119(1) 181-199

Keh, Hean Tat., Park, Il Hye., Kelly, Sarah., \& Du, Xiaomeng. (2016). The Effects of Model Size and Race on Chinese Consumers' Reactions : A Social Comparison Perspective. Psychology \& Marketing, Vol. 33(3): 177-194

Keller, L.L. (1993). Conceptualising, measuring and managing customer based brand equity. Journal of Marketing. (57) 1:1-22.

Khalid, Afia \& Qadeer, Faisal. (2017). Rising Consumer Materialism: A Threat to Sustainable Happiness. Routledge.

Kotler, Philip \& Armstrong, Gary. (2010). Principles of Marketing 13th Edition. New Jersey: Pearson Prentice Hall.

Kotler, P., \& Amstrong. (2002). Prinsip-Prinsip Pemasaran, Edisi Keenam, Erlangga. Jakarta

Ladero, M. Mercedes Galan., Casquet, Clementina Galera., \& Singht, Jaywant., (2015). Understanding factors influencing consumer attitudes toward cause-related marketing. International Journal of Nonprofit and Voluntary Sector Marketing Int. J. Nonprofit Volunt. Sect. Mark. 20: 52-70.

Lipovčan, Ljiljana Kaliterna., Prizmić-Larsen, Zvjezdana., \& Brkljačić1, Tihana. (2015). Materialism, affective states, and life satisfaction: case of Croatia. Lipovčan et al. SpringerPlus (2015) 4:699.

Matthews, Delisia \& Rothenberg, Lori. (2017). An assessment of organic apparel, environmental 
beliefs and consumer preferences via fashion innovativeness. International Journal of Consumer Studies.

Moslehpour, Massoud., Wong, Wing-Keung., Kien Van Pham, \& Carrine K. Aulia. (2017). Repurchase intention of Korean beauty products among Taiwanese consumers. Asia Pacific Journal of Marketing and Logistics, Vol. 29 Issue: 3

Narimawati. (2008). Metodologi Penelitian Kualitatif dan Kuantitatif: Teori dan Aplikasi. Bandung.

Prakash, Gyan., Kumar, Pankaj Singh., \& Yadav, Rambalak. (2018). Application of Consumer Style Inventory (CSI) to predict young Indian consumer's intention to purchase organic food products. Food Quality and Preference.

Razak, Themba \& Sjahruddin. (2019). Brand awareness as predictors of repurchase intention: Brand attitude as a moderator. Advances in Social Sciences Research Journal - Vol.6, No.2

Sharda, Nikita \& Bhat, Anil Kumar., (2017). Austerity to materialism and brand consciousness: luxury consumption in India. Journal of Fashion Marketing and Management. 1361-2026.

Siddique, Sobia \& Rashidi, Muhammad Zaki. (2015). Influence of Social Media on Brand Consciousness: A Study of Apparel in Karachi. Global Journal of Management and Business Research : EMarketing, Volume 15, Issue 6 Version 1.0, Year 2015.

Shao, W., Grace, D., \& Ross, M. (2019). Investigating brand visibility in luxury consumption. Journal of Retailing and Consumer Services. Elsevier, Vol. 49(C), pages 357-370.

Sharda, Nikita \& Bhat, Anil. (2019). Role of consumer vanity and the mediating effect of brand consciousness in luxury consumption. Journal of Product \& Brand Management.

Su, Jin. \& Tong, Xiao. (2020). An empirical study on Chinese adolescents' fashion involvement. International Journal of Consumer Studies.

Sutisna. (2001). Perilaku Konsumen dan Komunikasi Pemasaran. Bandung: PT Remaja Rosdakarya.

Szczepaniak, Magdalena. (2015). Fashion Involvement and Innovativeness, Self-Expression through Fashion and Impulsive Buying as Segmentation Criteria: Identifying Consumer Profiles in the Turkish Market. Entrepreneurship and Innovation Management Journal. Volume 3, Issue 1, Pages: 1-14.

Tjiptono, Fandy. (2005). Brand Management \& Strategy. Yogyakarta: Penerbit Andi.

Wang, Y. \& Wang, Y. (2016). Social stratification, materialism, post-materialism and consumption values An empirical study of a Chinese sample. Asia Pacific Journal of Marketing and Logistics.

Phui Mun, Wong. \& Apparavu, Kantharow., (2016). An Explanatory Study on Customer Loyalty, Brand Consciousness, Trusting Beliefs towards Online Purchasing Behaviour among Malaysian Undergraduates. Electronic Journal of Business and Management. Vol. 1, No. 1, (2016), pp.45-55.

Wheeler, Ladd \& Suls, Jerry. (2015). Social Comparison, Psychology of. International Encyclopedia of the Social \& Behavioral Sciences, 2nd edition, Volume 22.

Zheng, Xiaoying., Baskin, Ernest., \& Peng, Siqing. (2018). Feeling inferior, showing off: The effect of nonmaterial social comparisons on conspicuous consumption. Journal of Business Research : 90 (2018) 196-205. 